\title{
Design and Development of Solar Assisted Hydroponic Maize Fodder Gadget
}

\author{
Vivek R. Kamat ${ }^{*}$, Vidya Kulkarni ${ }^{2}$, V. Raghavendra ${ }^{2}$ and M. Veerangouda ${ }^{2}$ \\ ${ }^{1}$ Department of FMPE, COAE\&T, CCSHAU, Hisar, Haryana-125004, India \\ ${ }^{2}$ Department of FMPE, CAE, UAS, Raichur, Karnataka-584104, India \\ *Corresponding author
}

\begin{tabular}{|c|}
\hline Keywords \\
\hline $\begin{array}{l}\text { Hydroponics, } \\
\text { Protein, Crude } \\
\text { fiber, Crude protein, } \\
\text { Solar and fodder }\end{array}$ \\
\hline Article Info \\
\hline $\begin{array}{l}\text { Accepted: } \\
\text { 04 February } 2018 \\
\text { Available Online: } \\
10 \text { March } 2018\end{array}$ \\
\hline
\end{tabular}

\section{A B S T R A C T}

The project describes the development of a hydroponic system using solar panel to control light and water pump using an automatic time controller and also to minimize operational cost up to $40 \%$, to maintain continuity of renewable energy source and to release dependency from electric utility. Solar power is ideally used in India due to location factor and also gives the benefit to the environment as renewable energy. The solar assisted hydroponic green fodder gadget consists of solar panel, battery, micro sprinklers and automatic time controller. The collected solar radiations are converted into electrical energy and stored in battery with an average output of $12 \mathrm{~V}$ while maximum output voltage of $18 \mathrm{~V}$. The growth of the fodder crop mainly depends on moisture, temperature, $\mathrm{RH}$ and irrigation. Hence an automatic time controller is used to control the operation of hydroponic system for switching water pump, battery charge, discharge state and automatic micro sprinklers will be used to control moisture, temperature, $\mathrm{RH}$ and irrigation. The $10^{\text {th }}$ day fodder is harvested and laboratory test were carried out to study the content of crude protein, crude fiber, ether extract, total ash and acid insoluble ash and moisture content. Test revealed that crude protein $(\%) 13.2$, ether extract $(\%) 3.3$, crude fiber (\%) 15.02, total ash (\%) 2.35, acid insoluble ash (\%) 0.33 and moisture content (\%) 83.87. The increased nutritional content may be due to increased conversion efficiency. It is observed that during normal climatic condition the PV module produced power in the range of 7.1 to $17.29 \mathrm{~W}$ from 10:00 am to 04:00 pm in the month of April and May.

\section{Introduction}

Dairying is an important source of subsidiary income to small and marginal farmers and agricultural laborers. In addition to milk, the manure from animals provides a good source of organic matter for improving soil fertility and crop yields (Nabard). Green fodder is the natural diet of cattle. Green fodder is the most viable method to not only enhance milk production, but to also bring about a qualitative change in the milk produced by enhancing the content of unsaturated fat, Omega 3 fatty acids, vitamins, minerals and carotenoids (Nalanda Halchal). Hydroponics is Greek word, in which 'hydro' means water and 'ponics' means working, on the whole hydroponic means working with water (Gericke, 1937). Here, fodder crops are produced in water or nutritional rich solution, 
as it is staple food for dairy animals. Inclusion of green fodder in ration of dairy animals decreases the amount of concentrate feeding and thus increases the profit. For economical and sustainable dairy farming fodder production round the year is highly essential, as feeding of green fodder to dairy animals could play an important role. Solar energy can be an important part of India's plan not only to add new capacity but also to increase energy security, address environmental concerns, and lead the massive market for renewable energy (Sharma et al., 2012). Solar assisted hydroponic gadget requires less maintenance compared to electricity. The present generation is concentrating on utilization of renewable energy sources like solar energy, wind energy, geothermal energy, tidal energy and hydropower. Solar energy is most popular energy source applied for hydroponic green fodder production. The major cause is electricity supply in many villages continuous electricity supply is not provided; in hydroponics irrigation is done at periodic time interval. If electricity is not supplied properly results in improper application of water, if water is not applied properly fodder gets affected by fungus and bacteria. The fungus affected fodder is dangerous for the cattle health. The power is used only in day time hence solar energy can be utilized during rainy and winter seasons also hence, solar assisted hydroponic gadget is designed, developed and performance is evaluated at Raichur.

\section{Materials and Methods}

The research work was undertaken at the Department of Farm Machinery and Power Engineering, College of Agricultural Engineering Raichur, Karnataka. Raichur is suited on the latitude of $16^{0} 15^{\prime}$ north, longitude of $77^{0} 21^{\prime}$ east and at an elevation of 389 meters above mean sea level which is considered as North Eastern Dry Zone of Karnataka. This chapter deals with the materials used and methods followed in conducting design and development of solar assisted hydroponic green fodder gadget. The main emphasis was to study the solar operated gadget by measuring solar intensity, current (A), voltage (V) and power (W).

The solar photovoltaic panel of 20W has been purchased and installed at centre and were used to generate the power to run pump. DC Ammeter, DC voltmeter, solar intensity meter and thermometer were used to measure DC current, DC voltage, direct solar intensity and ambient temperature respectively.

\section{Power transmission system}

The hydroponic gadget is provided with PV module which is the main source of energy for other working components of gadget. The electric power generated by PV module is initially stored in battery, input of battery is connected to the controlling unit and output of pump is also connected to the controlling unit. The input of pump is connected to the water tank. As the pump gets drive from the DC motor suction pressure is generated in the suction pipe oh the pump which lifts the water to the laterals connected and the water is sprinkled to the trays in the set up with the required pressure. The block diagram of the hydroponic gadget is presented in the Figure 2.

The chemical compositions like moisture content, crude protein, crude fiber, ether extract, total ash and acid insoluble ash were determined according AOAC standards (AOAC, 1980).

\section{Moisture content}

The moisture content of fresh and dry fodder was determined by hot air oven method (AOAC, 1980). 
Moisture content $=\frac{w 2-w 1}{w 3}$

Where,

$\mathrm{W}_{1}=$ initial weight of sample $(\mathrm{g})$

$\mathrm{W}_{2}$ = final weight of sample $(\mathrm{g})$ and

$\mathrm{W}_{3}=$ weight of dried sample in grams

\section{Crude protein}

The crude protein in hydroponic fodder was determined by using micro Kjeldhal method (AOAC 1980).

Protein $\%=$ weight of sample (g)xaliquotused in distillation(ml)

Where, $\mathrm{TV}=$ titre value

\section{Crude fiber}

The crude fiber in hydroponic fodder is determined by the sequential acid and alkali hydrolysis method using Fibra-plus apparatus (AOAC, 1980).

Crude fiber $(\%)=\frac{w 1-w 2}{w} \times 100$

Where,

$\mathrm{W}_{1}=$ weight of the sample before ashing $(\mathrm{g})$

$\mathrm{W}_{2}=$ weight of sample after ashing $(\mathrm{g})$

\section{Estimation of ether extract and total ash}

Ether extract is done using soxhlet apparatus and principle involved is that when a known weight of feed is ignited to ash.

The weight of ash thus obtained is expressed in terms of percentage.

\section{Analytical calculation of panel current and discharge time of battery}

The current produced by the solar panel (I) was calculated by knowing the maximum power $(\mathrm{P})$ of the solar panel and voltage rating $(\mathrm{V})$ of the battery that is given by

$$
\begin{aligned}
& I=\frac{\mathrm{p}}{\mathrm{V}}, \mathrm{A} \\
& \mathrm{I}={ }^{\frac{20}{12}}, \mathrm{~A}
\end{aligned}
$$

$\mathrm{I}=1.67 \mathrm{~A}$.

Charging time ( $\mathrm{T}$ ) was computed by taking the ratio rating of the battery in ampere hour (Ah) to the total current consumed by the solar panel.

$$
\begin{aligned}
& \mathrm{T}=\frac{\text { Battery rating in ampere hour }}{\text { total current consumed by the solar panel }} \\
& \mathrm{T}=\frac{7.2}{1.67} \mathrm{~h} \\
& \mathrm{~T}=4.31 \mathrm{~h} .
\end{aligned}
$$

Calibration of solar operated hydroponic green fodder gadget

The seeds were soaked in water for 24 hours and spread in the hydroponic tray, each tray can hold $1.5 \mathrm{~kg}$ of seeds likewise 12 trays are placed in the set up the whole set up is closed (one half is closed with black tarpaulin and other half by green shade net) to hold the solar radiation.

Using controlling unit the frequency, duration and time of spraying is controlled such that the spraying is done only in the day time.

At the end of the $10^{\text {th }}$ day root to shoot ratio was measured and compared with the standard. 


\section{Results and Discussion}

The laboratory test were carried out to study the content of crude protein, crude fibre, ether extract, total ash, acid insoluble ash and moisture content conducted to evaluate the performance of solar operated hydroponic green fodder gadget is presented and discussed in this chapter. During the laboratory test parameters like weight of the sample, titre value, dry weight of sample are tabulated, whereas during field experiments observations such as time, temperature, voltage, current, power are recorded and explained below.

\section{Results of lab test}

The $10^{\text {th }}$ day fodder was harvested and sample was prepared to carry out the experiments in laboratory.

\section{Moisture content (\%)}

The hydroponic fodder of $10^{\text {th }}$ day is chopped into small pieces and kept is hot air oven the average moisture content found $83.87 \%$. The moisture content in hydroponic fodder is high because the fodder is grown under water.

Chemical properties like crude protein, crude fiber, ether extract, total ash and acid insoluble ash are determined with hydroponic fodder and conventional fodder. The values are tabulated in below Table 2 .

The crude protein, ether extract, crude fiber, was found to be higher in hydroponic fodder compared to conventional farming fodder as shown in the table 2. It may be due to increased conversion efficiency as hydroponic fodder was grown in controlled condition

\section{Results of field evaluation}

The performance evaluation of solar operated hydroponic gadget is conducted under normal climatic conditions. For evaluation the observations such as voltage, current and power are tabulated for corresponding change in surrounding temperature and solar intensity at regular intervals. To understand the variation of change in one parameter with respect to other we need to plot the following graphs (Figure 3, 4, 5 and 6).

Variation of voltage with respect to solar intensity is presented in the Figure 3. The voltage values will be in the range of $19.18 \mathrm{~V}$ $19.40 \mathrm{~V}$ for corresponding change in values of solar intensity ranging from $595.14 \mathrm{~W} / \mathrm{m}^{2}$ $723.14 \mathrm{~W} / \mathrm{m}^{2}$ respectively. Hence the graph shows that increase in solar intensity increases the voltage.

Variation of current with respect to solar intensity is presented in the Figure 4. The current values will be in the range of $0.41 \mathrm{~A}$ $0.71 \mathrm{~A}$ for corresponding change in values of solar intensity ranging from $595.12 \mathrm{~W} / \mathrm{m}^{2}$ $723.14 \mathrm{~W} / \mathrm{m}^{2}$ respectively.

Variation of power with respect to solar intensity is presented in the Figure 5. The power generated values will be in a range of 9.21 W-13.81 W for corresponding change in values of solar intensity ranging from 595.14 $\mathrm{W} / \mathrm{m}^{2}-723.14 \mathrm{~W} / \mathrm{m}^{2}$ respectively.

Variation of power with respect to solar intensity is presented in the Figure 6. The test temperature values will be in range of $29{ }^{\circ} \mathrm{C}$ $35{ }^{\circ} \mathrm{C}$ for corresponding change in the solar intensity ranging from $595.14 \mathrm{~W} / \mathrm{m}^{2}-723.14$ $\mathrm{W} / \mathrm{m}^{2}$ respectively.

The solar operated hydroponic green fodder gadget was developed and evaluated to utilize the available solar energy and to release the dependency from the use of electricity. This gadget was developed to produce green fodder by the hydroponic techniques, maize seed was used during this experiment. 
Table.1 Construction details of solar operated hydroponic gadget

\begin{tabular}{|c|c|c|}
\hline Sl. No & Parameters & Details \\
\hline & Name of the gadget & Solar Operated Hydroponic Green Fodder Gadget \\
\hline & Specification of the gadget & \\
\hline \multirow[t]{5}{*}{1} & Panel description & \\
\hline & (a) maximum power $\left(\mathrm{P}_{\max }\right)$ & 20WP \\
\hline & (b) maximum power voltage $\left(\mathrm{V}_{\mathrm{mP}}\right)$ & $16 \mathrm{~V}$ \\
\hline & (c) maximum power current $\left(\mathrm{I}_{\mathrm{mp}}\right)$ & $1.25 \mathrm{~A}$ \\
\hline & (d) no: of panels & 1 \\
\hline \multirow[t]{4}{*}{2} & Description of DC pump & \\
\hline & (a) type of pump & Diaphragm pump \\
\hline & (b) discharge $(\mathrm{Q})$ & $4 \mathrm{Lt} / \mathrm{min}$ \\
\hline & (c) pressure $\left(\mathrm{P}_{\mathrm{r}}\right)$ & 100psi \\
\hline \multirow[t]{5}{*}{3} & Battery description & \\
\hline & (a) type of battery & Sealed Lead Acid Dry Type \\
\hline & (b) voltage $(\mathrm{V})$ & $12 \mathrm{~V}$ \\
\hline & (c)current(I) & $7.2 \mathrm{~A}$ \\
\hline & (d) power(P) & 86.4WP \\
\hline 4 & Laterals & 4 \\
\hline 5 & Micro -sprinklers & 20 \\
\hline 6 & Hydroponic tray & 18 \\
\hline 7 & Water tank & I tank with capacity $40 \mathrm{lt}$ \\
\hline
\end{tabular}

Table.2 Comparison of nutrient content of conventionally grown fodder and hydroponically grown fodder

\begin{tabular}{|c|}
\hline Nutrient \\
\hline Crude protein (\%) \\
\hline Ether extract (\%) \\
\hline Crude fibre (\%) \\
\hline Total ash (\%) \\
\hline Acid insoluble ash (\%) \\
\hline
\end{tabular}

\begin{tabular}{|c|}
\hline Conventional farming fodder \\
\hline 10.36 \\
2.30 \\
25.89 \\
9.40 \\
1.50 \\
\hline
\end{tabular}

\section{Hydroponic fodder}

\begin{tabular}{|c|}
\hline 13.2 \\
\hline 3.3 \\
\hline 15.02 \\
\hline 2.35 \\
\hline 0.33 \\
\hline
\end{tabular}

Fig.1 Line diagram of power transmission system of solar operated hydroponic green fodder gadget drawn by using AUTO-CAD

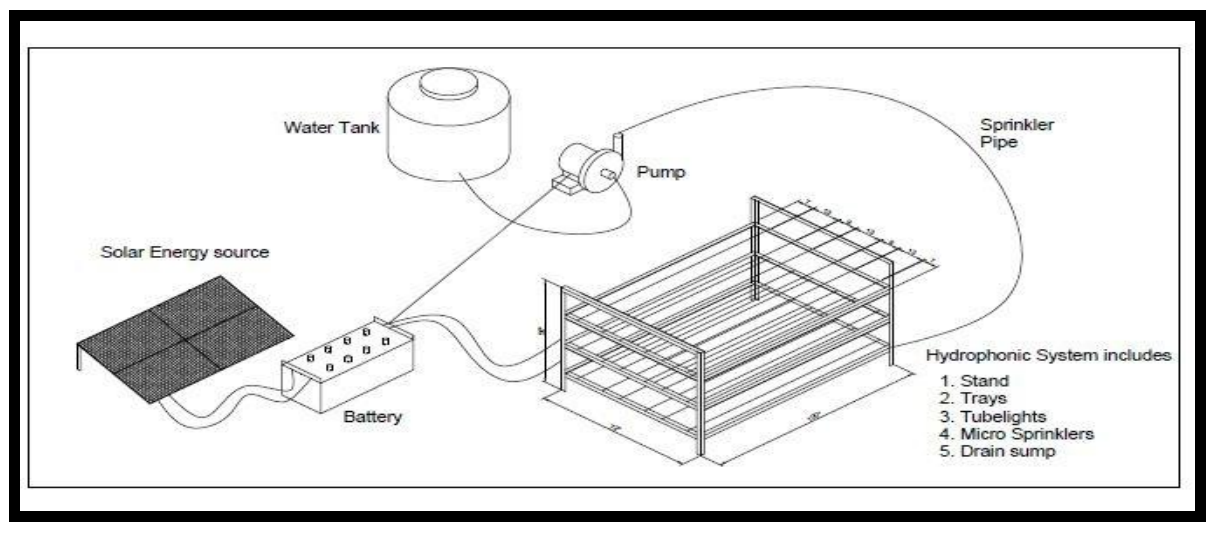


Fig.2 Power transmission of solar operated hydroponic gadget

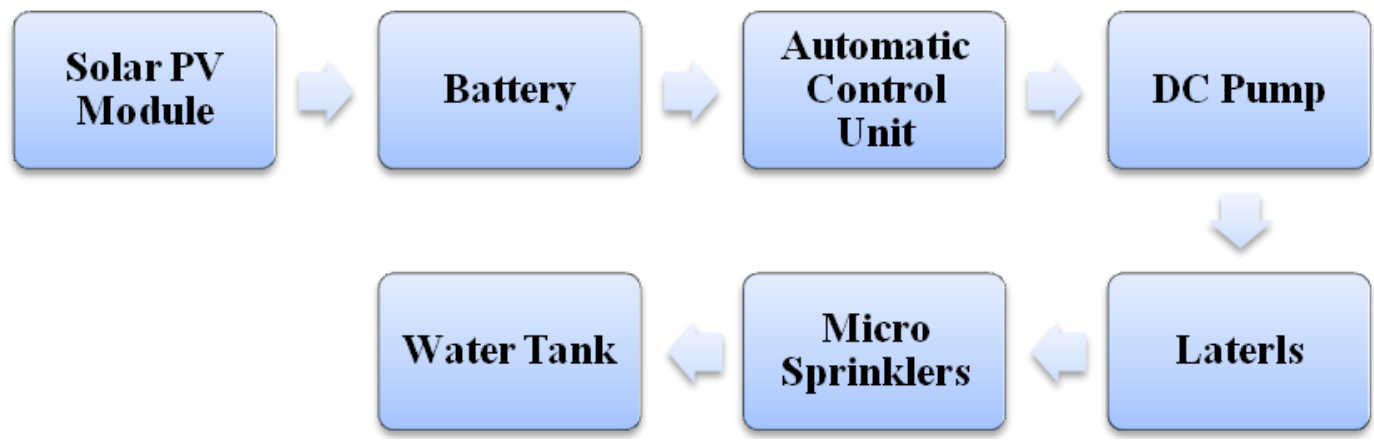

Fig.3 Variation of panel voltage with respect to solar intensity

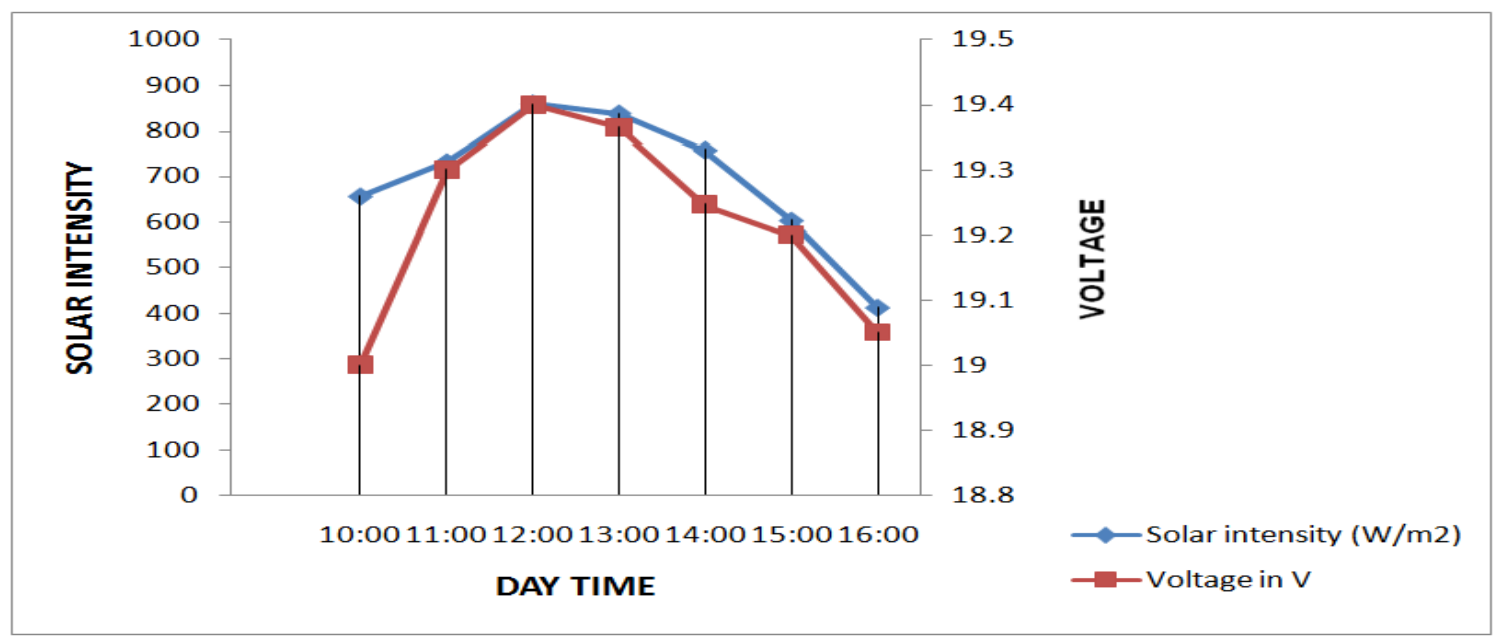

Fig.4 Variation of panel current with respect to solar intensity

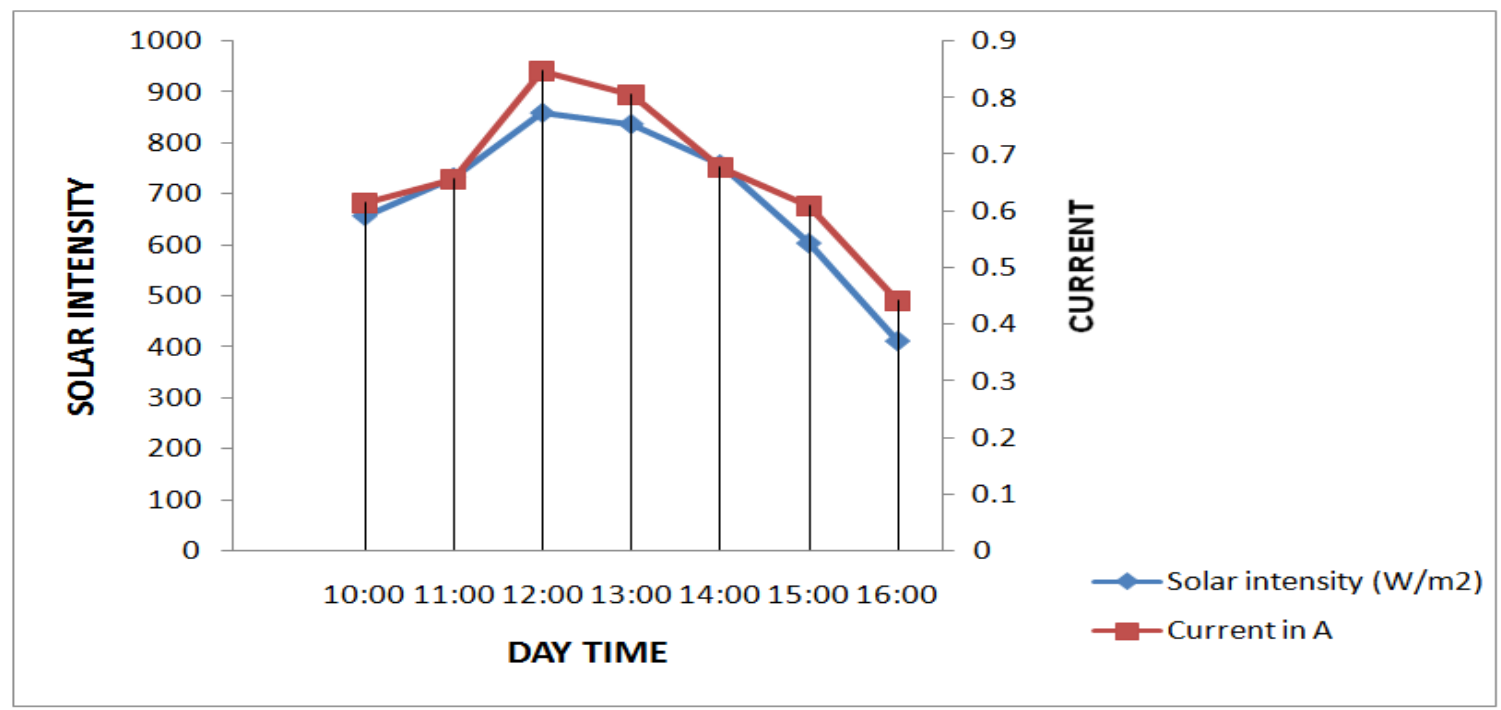


Fig.5 Variation of panel power with respect to solar intensity

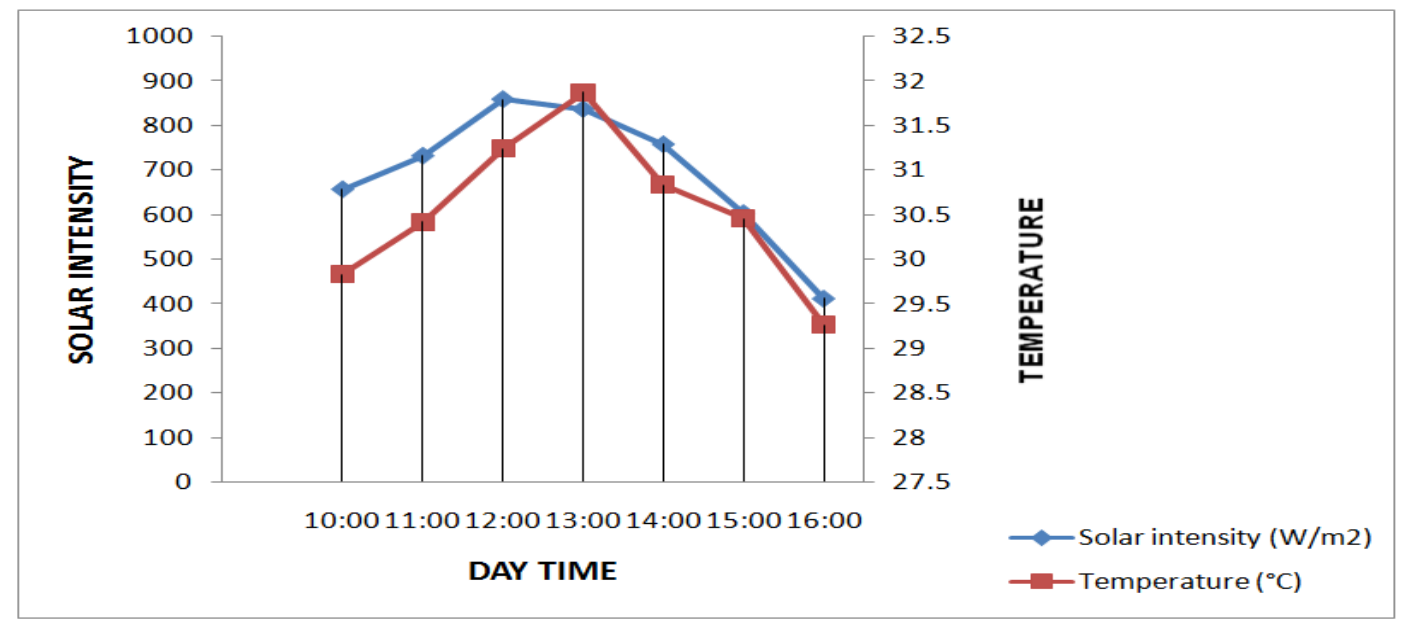

Fig.6 Variation of surrounding temperature with respect to solar intensity

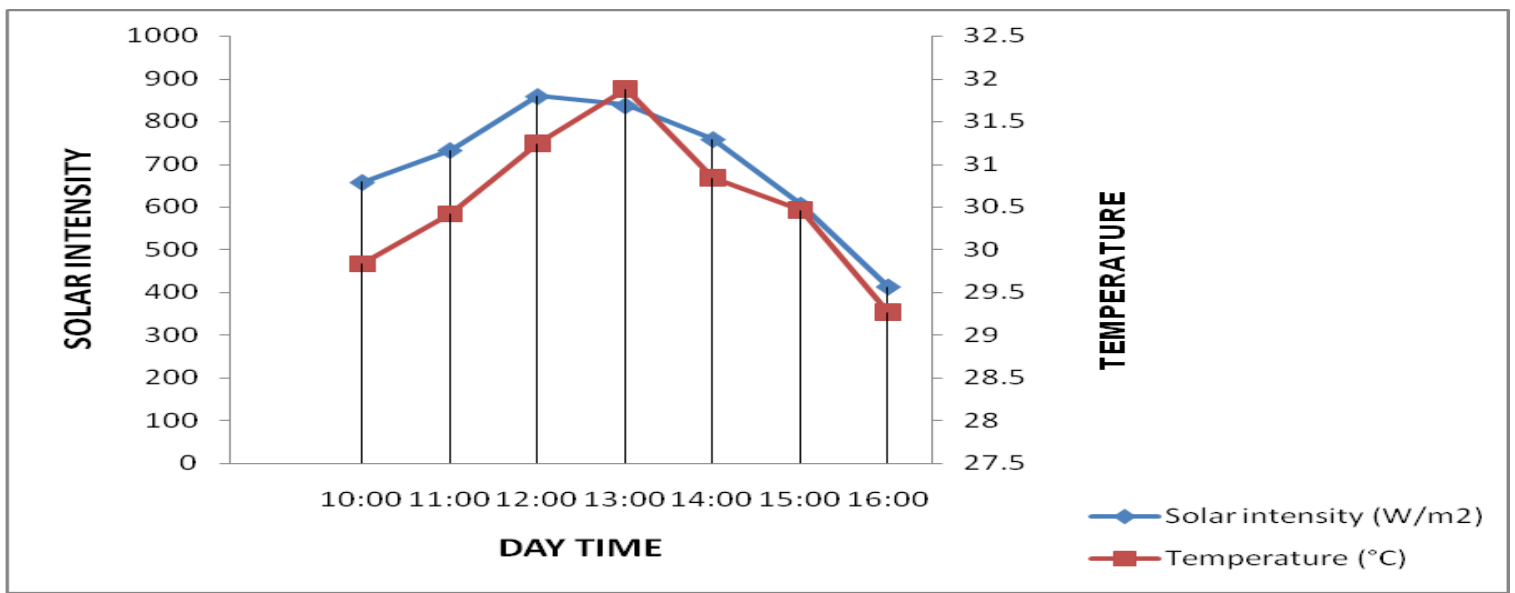

Plate.1 A view of solar operated hydroponic gadget

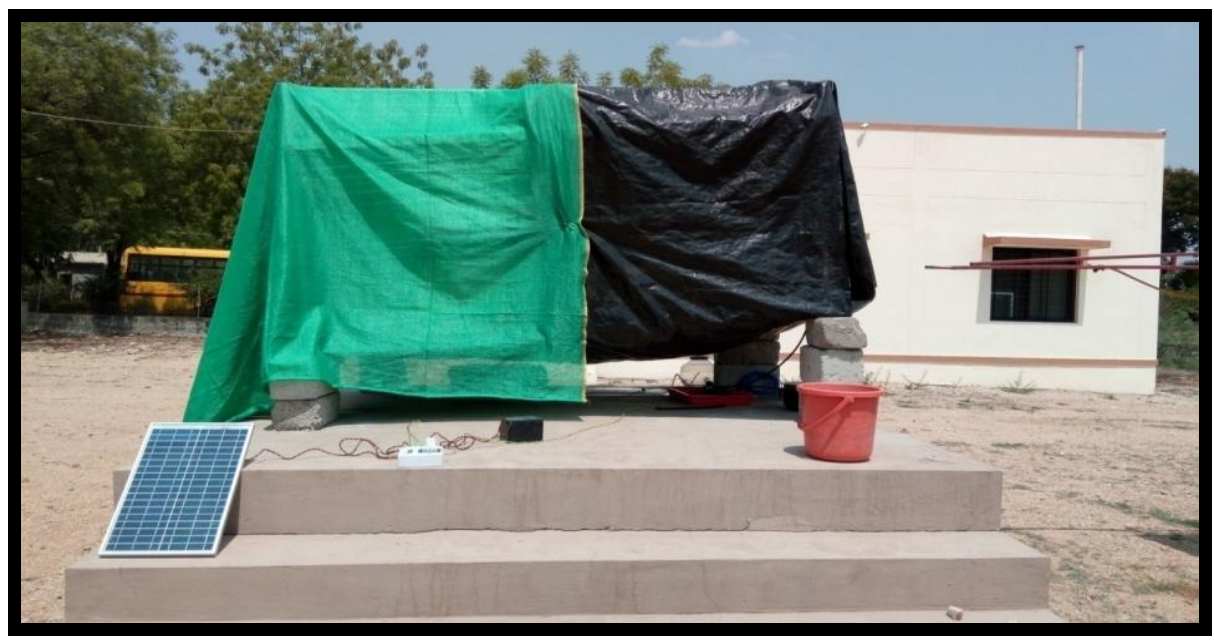


Solar assisted hydroponic gadget is specially designed for green fodder and small and marginal farmers easily adopt this gadget for the fodder production for their cattle. It is found there is $13 \%$ increase in the milk yield by feeding hydroponic maize fodder (Niak et al., 2014).

Based on the laboratory test and performance evaluation, the following conclusions are drawn out from the study.

Solar operated green fodder gadget utilizes energy from solar. Hence its saves energy cost.

Solar powered hydroponic gadget produces good quality of green fodder.

This gadget saves $60 \%$ of water usage.

The battery took 3 hours for complete discharge

This solar powered hydroponic gadget maintains optimum temperature and light by automatic controller. Hence there is no need of man power to operate this gadget

This machine produces good quality of fodder throughout the year
Hydroponic fodder is highly palatable and nutritious fodder comparable to commercial feed.

\section{References}

AOAC, 1980, Official methods of analysis $10^{\text {th }}$ edition. Association of official agricultural chemists, Washington, D.C.

Gericke, W.F., 1937. Hydroponics -Crop production in liquid culture media. Science, 85(2198), pp.177-178

NABARD, Dairy farming project http://retawprojects.com/uploads/g10.pdf

Nalanda Chanchal, http://nalandahalchal. blogspot.in/2017/10/what-is-hydro ponics.html

Niak, P. K., Dhuri, R. B., Karunakaran, M., Swain, B. K and Singh, N, P. 2014. Effect of feeding hydroponic maize fodder on digestibility of nutrients and milk production in lactating cows, Indian journal of animal sciences 84(8):880-883.

Sharma, N.K., Tiwari, P.K. and Sood, Y.R., 2012. Solar energy in India: Strategies, policies, perspectives and future potential. Renewable and Sustainable Energy Reviews, 16(1), pp.933-941.

\section{How to cite this article:}

Vivek R. Kamat, Vidya Kulkarni, V. Raghavendra and Veerangouda, M. 2018. Design and Development of Solar Assisted Hydroponic Maize Fodder Gadget. Int.J.Curr.Microbiol.App.Sci. 7(03): 124-131. doi: https://doi.org/10.20546/ijcmas.2018.703.014 